\title{
Authoritarian state building through political decentralization and local government law: Evidence from the Islamic Republic of Iran
}

\author{
OÑATI SOCIO-LEGAL SERIES Volume 10, Issue 5 (2020), 1040-1074: HistoricAl AND COMPARATIVE \\ MACROSOCIOLOGY OF MidDLE EASTERN LEGAL SYSTEMS \\ DOI LINK: HTTPS://DOI.ORG/10.35295/OSLS.IISL/0000-0000-0000-1029 \\ RECEIVED 04 SEPTEMBER 2018, ACCEPTED 12 FEBRUARY 2019
}

\section{KIAN TAJBAKHSH* ID}

\section{Abstract}

What motivates ideological authoritarian regimes to permit subnational elections? What mechanisms do these regimes employ to ensure that local electoral outcomes are favorable to the regime? Focusing on the decision to create a new tier of elected local government and the use of local government law, I argue that national elites can use local elections to strengthen state-building through increased institutionalization of mass political participation and by integrating local populations into the ambit of state controlled public goods provision. I illustrate this argument by analyzing elected local government in the Islamic Republic of Iran. I show how the state's legal framework successfully constrains local actors in three contested domains: the scope of political participation, the extent of legislative authority, and the degree of fiscal autonomy. A

I would like to acknowledge the helpful comments on an earlier draft by Dr. Charles Kurzman, Dr. Nathan Brown and two anonymous reviewers. This paper was presented at the workshop on Historical and Comparative Macrosociology of Middle Eastern Legal Systems. 24-25 May 2018, International Institute for the Sociology of Law (IISL), Oñati, Spain. I would like to express my appreciation to the organizers, Professor Said Amir Arjomand and Professor Nathan Brown.

* Columbia University. Contact details: Columbia Global Centers, 91 Claremont Ave., Suite 529, New York, NY 10027, USA. Email address: kt242@columbia.edu

Errata. Because of a production error in the editing stage, some incorrections appeared in this article. OSLS regrets the error. The following corrections have been made:

p. 1040: Author contact details: Columbia Global Centers, 91 Claremont Ave., Suite 529, New York, NY 10027, USA (Graduate School of Architecture, Planning and Preservation, 1172 Amsterdam Avenue, New York (NY) 10027, USA has been removed).

p. 1044, para. 4: "one set of answers" instead of "one set answers".

p. 1047, para. 1: The word "reinforcing" in the sentence "which facilitates political capture and reinforcing centralized party control" has been removed.

p. 1047, para. 3: The sentence "In highly ideological regimes, particularly highly institutionalized authoritarian ones" has been removed.

p. 1049: In the sentence "the draft proposed decentralizing some functions of public administration to local government and to have to transform mayors form appointees" now reads "the draft proposed decentralizing some functions of public administration to local government and to transform mayors from appointees".

p. 1057, para. 2: The figure " $2 \%$ " should have been " $5 \%$ "; this has been changed. 
major implication of these findings is that expanding participation through subnational elected government in an ideological Islamist regime contributes to authoritarian nationstate building.

\section{Key words}

Iran; decentralization; elections; authoritarianism; local government law; nationbuilding; democracy

\section{Resumen}

¿Qué motiva a los regímenes autoritarios ideológicos a permitir elecciones subnacionales? ¿Qué mecanismos emplean para asegurarse de que los resultados de las elecciones locales les son favorables? Argumentamos aquí que las elites nacionales pueden utilizar las elecciones locales para fortalecer la construcción del Estado a través de una creciente institucionalización de la participación política masiva y de la integración de poblaciones locales en el ámbito de las provisiones de bienes controlados por el Estado. Ilustramos ese argumento con un análisis del gobierno local electo en la República Islámica de Irán. El marco jurídico del Estado limita a los agentes locales en la participación política, la autoridad legislativa y la autonomía fiscal. Una importante implicación de estos hallazgos es que la expansión de la participación a través de un gobierno subnacional electo en un régimen ideológico islamista contribuye a la construcción del Estado-nación autoritario.

\section{Palabras clave}

Irán; descentralización; elecciones; autoritarismo; leyes de gobierno local; construcción nacional; democracia 


\section{Table of contents}

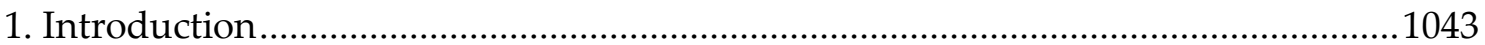

2. Elections and Decentralization under Authoritarianism .......................................... 1045

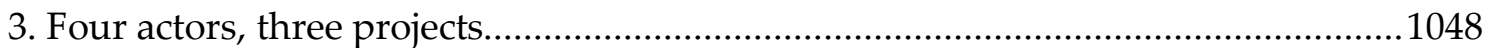

4. Motivations for Creating elected local government in Iran .......................................1048

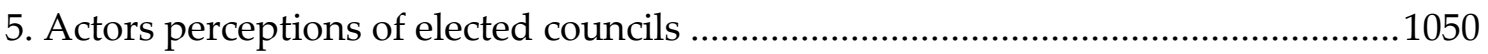

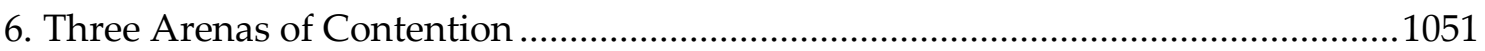

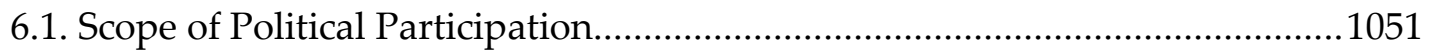

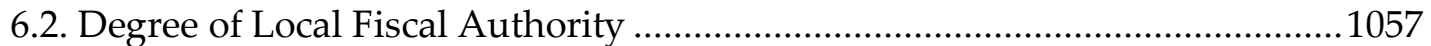

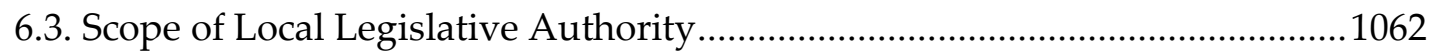

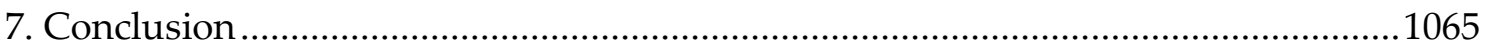

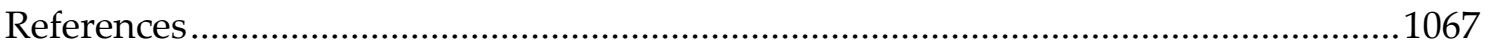




\section{Introduction}

Elections are a central feature of state-building in many countries around the world, including in both democratic and authoritarian regimes. Modern nation-state building is a process of forging an ensemble of institutions claiming exclusive sovereignty and the monopoly of the means of coercion over a given territory and its population, usually accompanied by a set of ideological or nationalist narratives legitimizing the right to rule (Offe 1998, Weber 2013, p. 56). The fundamental processes of state-building involve political institutionalization combining the centralization of power (Tilly 1975) but also at the same time the increasing differentiation of the institutions of governance. The purpose is to make the state more adaptable, complex, autonomous, and coherent in the face of intensifying and changing demands of populations. Such demands are prompted by the dislocation of the population by the transformations wrought by modernization processes. Such changes are often instigated by the state itself, usually in conjunction with technological and market driven change (Huntington 2006, Fukuyama 2012, Acemoglu 2013).

Autocratic systems ${ }^{1}$ are prone to instability where state power is unconstrained and where there is an absence of political participation through which the state can address the interests of vulnerable interest groups; hence the cycle of rebellion and repression that has characterized most of human history. To avoid instability, state-builders may seek to enhance the legitimacy of decision-making institutions by integrating social groups and interests into the process of governance through granting concessions most importantly through political rights to participate in elections. (Additional means of assuaging demands are ensuring the legal and physical infrastructure necessary for accessing markets and bureaucratically supplying a range of social benefits such as education, health care, security and other public goods.) Given the number of dictatorships around the world that regularly hold elections, it is obviously erroneous to assume that electoral participation is necessarily democratic, in the robust sense of a majority of citizens effectively ruling the state managed by elites and experts. ${ }^{2}$ Liberal democratic states are distinctive not merely because they hold elections but because they strive to design laws and institutions that protect individuals against arbitrary power and in promoting an open society in which government policy is responsive to multiple interests arising independently and freely from civil society (Katznelson 2003, p. 108). As a tool of such endeavors, ideally, elections play a crucial role in transferring societal values into the policy-making institutions of government. Thus, while almost all countries in the world today employ elections for selecting top national leadership

\footnotetext{
${ }^{1}$ I follow the literature is using "autocracy" and "authoritarians" interchangeably as a matter of style. Strictly speaking they are not equivalent forms of regime.

2 I use the definition of democracy Juan Linz offers in his classic essay on regime typologies. A regime can be regarded as democratic "when it allows for the free formulation of political preferences, through the use of basic freedoms of association, information, and communication, for the purpose of free competition between leaders to validate at regular intervals by nonviolent means their claim to rule (...) without excluding any effective political office from that competition or prohibiting any members of the political community from expressing their preference" (Linz 1975). Linz's definition is also compatible with Robert Dahl's (1998) concept of "polyarchy", a system of rule by minorities in a context of dispersed inequalities that is ultimately open to popular challenge. Both definitions imply that electoral outcomes only possess democratic legitimacy under a range of preconditions in place before, during, and after the act of voting (Offe 2006).
} 
(China and Iran are notable exceptions), their significance depends crucially on the nature of the regime as well as the design of state institutions.

This paper focuses on the degree and type of centralization of the state administrative structure and the intergovernmental system and its relation to local elections. I distinguish between two qualitatively different ways the scholarly literature uses the term centralization in relation to the modern state; the contrast between them plays a key role in this paper. In the first sense, centralization connotes the rationalization of authority, a process of increasing state capacity through enhancing the coherence and efficiency of bureaucratic institutions; this idea played a key role in influential theories of political development and institutionalization (Huntington 2006, Fukuyama 2012). In an entirely different sense, which we owe most prominently to Tocqueville, centralization of authority describes the increasing monopoly or concentration of power throughout society by a "monistic" state, which causes the weakening of independent social or intermediate associations of civil society (Nisbet 1976). Liberal democratic states ideally seek to disperse power centers as a check on the dangers of despotism and unaccountable power; this is expressed horizontally by the separation of branches or functions of government (including the political control over the bureaucracy), and vertically through checking and balancing central power by lower levels of government, regional or local interests, the private sector, civil society associations, media and so on - in sum, by what Dahl called a "pluralistic social order" (Dahl 1998). Yet to function efficiently even liberal democratic states must at the same time rationalize government institutions. By contrast, authoritarian states ${ }^{3}$ ensure their domination of their societies typically by concentrating power both functionally in a limited number of power centers (such as when a single office or person controls executive, judicial, and legislative power) and geographically, by centralizing power in the capital city, which then dominates the peripheries. This type of centralization usually undermines the strength of independent associations. But it is entirely possible for this concentration to go hand-in-hand with an increasing rationalization of the governmental institutions, achieving an efficient despotism.

In the light of the links between centralized state-building, participation, and elections, it is less obvious what motivates authoritarian states to initiate reforms for political decentralization whereby subnational jurisdictions, such as provinces, town, or villages hold elections. Promoting such dispersal at first sight would appear to be hazardous to authoritarian states even to those who have successfully emasculated national legislatures and effectively controlled national level elections. What do authoritarian regimes seek to gain from political decentralization which empowers subnational jurisdictions with the franchise, potentially mobilizing new arenas of electoral political participation which could then pose a threat to the ruling powers monopoly of power?

In this article I offer one set of answers to these questions through a study of political decentralization under the Islamic Republic of Iran (IRI), a unique theocratic political system that is nondemocratic and highly ideological. I show how political

\footnotetext{
${ }^{3}$ I used the term "authoritarian" to describe regimes where broadly speaking the state dominates society rather than the reverse. It is contrasted to democratic systems defined in note 1 above. I note however that the classic definition of "authoritarian regime" offered by Juan Linz (Linz and Stepan 1996, p. 38) may not be fully applicable to the case of Iran studied here for reasons that need not detain us.
} 
decentralization simultaneously increased state centralization and rationalization while blunting the potential threats posed by local electoral institutions mobilizing opposition to the regime. Decentralization, I argue, is thus one dimension of the authoritarian nation-state building project. At the same time the Iranian case differs from other examples of electoral authoritarianism in a number of ways. In particular, it is distinctive in framing the institutions of local governance in the idiom of a politicized religious ideology (Islamic councils).

\section{Elections and Decentralization under Authoritarianism}

The motivations for establishing local elections in non-democratic regimes is clearly related to the broader question of why autocracies hold elections at all. It is no longer a puzzle why dictatorships and anti-democratic authoritarian regimes hold national level elections regularly (Acemoglu and Robinson 2006, Gandhi and Przeworski 2006, Schedler 2006). ${ }^{4}$ Less studied is the role of subnational elections in authoritarian statebuilding. This is of particular importance since scholarship on electoral autocracy stresses that not all types of elections are of equal significance for state-building under autocracy (Gandhi and Lust-Okar 2009). The pervasiveness of decentralization initiatives across a wide range of regime types across the world since the 1980s, which one author describes as a decentralization revolution (Grindle 2009), has led an increasing number of scholars to study subnational elections.

Recent scholarship on decentralization has focused on three dimensions: the motivations prompting regimes to decentralize; the mechanisms through which authoritarian regimes use decentralization to control local actors to buttress centralized power; and, conversely, the ability of civil society actors to mobilize around subnational institutions of governance (on the last, see Putnam 1994, Mansuri and Rao 2012). ${ }^{5}$

One of the more striking findings of the literature is that in many cases political decentralization originated as a top-down initiative of national elites, including nonrepresentative rulers. Another finding is that achieving greater democratization of the polity through the dispersal of power is rarely the driving objective of decentralization. The findings of a wide range of cases across different regime types challenge the common perception that political decentralization is necessarily, or even usually, adopted by states in response to bottom-up social demands of local populations for greater voice or representation. In China, the top of the communist party established elected village committees in 1987 as a way to create a new rural leadership cadre after agricultural decollectivization threatened stability by undermining local social relations (Manion 1996); in Pakistan, a military dictatorship created elected local government to

\footnotetext{
${ }^{4}$ Although it should not really have been a surprise. Huntington observed in his classic study over fifty years ago that "broadened participation in politics may enhance control of the people by the government, as in totalitarian states, or it may enhance control of the government by the people, as in some democratic ones" (Huntington 2006, p. 34). Of course without the "liberal" qualification, merely popular control of government is perfectly compatible with totalitarian democracy, as the mass support for twentieth century fascism, communism, and totalitarianism bears out (Nisbet 2010, p. 178).

${ }_{5}$ A third strand of literature - which I do not consider in this paper - focusses on the outcomes of decentralization on range of economic (Bird and Vaillancourt 1998, Ebel and Yilmaz 2002, Bardhan and Mookherjee 2006), political (Bardhan and Mookherjee 2000, Khemani 2015) and social (Mansuri and Rao 2012) variables.
} 
undermine the power base of its civilian political opponents (Cheema et al. 2005, Bohlken 2016); in Ghana, the new military government instituted local elections to obfuscate the absence of accountability at the national level, as well as to impress international donors to maintain the aid programs to the country (Ayee 1997).

Another line of research seeks to identify in greater detail the conditions under which subnational electoral institutions strengthen authoritarian regimes. It finds that the capacity of elites (representative or non-representative) at the center (i.e. at the national level) to mobilize and harness political support in localities depends on the interplay of three key variables: (i) the extent of the ruling party's organizational networks at lower level jurisdictions through which it can mobilize local voters to its support; (ii) the capacity of the subnational level bureaucracies to deliver goods and services, which indirectly benefits the regime by responding to local needs (as in theories of ruling bargains (Kamrava 2014, Wimmer 2018); (iii) and third, the relative organizational strength of potentially oppositional local elites, including the national opposition parties local branches. Thus, ruling elites will have greater incentives to implement political decentralization and local elections where they lack extensive local party organizational networks (typical in militaristic or personalistic autocracies); where the subnational level bureaucracies are weak (as in many developing countries); and where potentially oppositional local elites are relatively strong.

Once electoral institutions are in place, authoritarian regimes face the challenge of preventing opponents from using local institutions to challenge the regime's monopoly of power. Regimes permit local elections when they are able to combine political decentralization with weak local fiscal authority; for instance, in her study of Ugandan local government, Lewis (2014) found that the dependence of local institutions on central government fiscal support promoted the centralization of power. Studying mayoral elections in Russia, Reuter and collaborators (2016) contend that the ruling national party uses elections to co-opt local elites who control powerful political machines by means of a bargain in which local elites retain access to local resources and authority in exchange for delivering local electoral political support for the ruling national party. Turkey is another case where the highly centralized design of local public finances has facilitated the consolidation and centralization of power of the ruling AKP party (Cammett and Luca 2018).

Decentralized local governance often include both elected and appointed officials, either of which may pose a threat to central government power holders, and so pose different challenges in controlling them. Landry (2008) has shown how in China the central authorities succeeded in overcoming the principal-agent problem of preventing lower level appointed officials from challenging their priorities through the careful manipulation of the party's appointment and promotion systems. China's effectiveness in "making autocracy work" (Truex 2016) challenges the conventional wisdom that decentralization renders local institutions harder to control; in fact, detailed studies have shown how it may facilitate central government control over local public goods provision and even over local civil society and associations (Teets 2014, Distelhorst and Hou 2017). Cleary's (2010) study of Mexican local elections identified yet another mechanism through which even authoritarian regimes that tolerate some dissent, public participation, and civic organizations can block democratization at the local level: where 
locally elected politicians have greater incentives to bring benefits to party superiors rather than to constituents political decentralization bolsters "local authoritarian enclaves," which facilitates political capture and reinforces centralized party control.

I draw from and build on this line of literature to identify several other variables that lead nondemocratic regimes to endorse and benefit from local electoral institutions. I argue that where the regime possesses enough control over the legislature and the electoral processes effectively blocking opposition parties from passing legislation attacking unaccountable power centers, regimes can support local elections because they carry few costs and some potential benefits for further expanding and strengthening the regime's institutions. Furthermore, where the regime's subnational organizational networks are strong and conversely where those of the potential opposition parties are weak or non-existent, local politics is unlikely to develop into an oppositional force threatening to the regime, even if decentralization is ineffective in efficiency or administrative terms. A third set of conditions draws on the literature on the political control of bureaucracy, which highlights the non-democratic bargaining between political and bureaucratic elites (Dahl 1998, 113, Eaton 2003). I argue that regimes can realize significant benefits from the public management efficiency of decentralization if their control of the bureaucratic channels for redistribution throughout all subnational jurisdictions is robust and potential opposition local forces have little likelihood of using bureaucracy and the inter-governmental system to distribute resources to local supporters. In such cases, obtaining benefit such as learning about local preferences and grievances will leads the regime to calculate that the benefits of political decentralization would outweigh the costs.

In addition to cost-benefit analysis, I highlight two factors related to political decentralization to which the scholarly literature has paid inadequate attention: the influence of ideology and the role of law. Thus a fourth variable important for understanding how authoritarian regimes control local electoral institutions focusses on the role of law in relation to local government sector. I argue that in addition to the several mechanisms the literature has already identified, a state's legal system can be an important mechanism of domination and control; the central regime can employ local government law to ensure that political decentralization redounds to its advantage. Greater institutionalization of the inter-governmental system through the legal framework decreases the threat of political decentralization to the regime. The legal system offers a low-cost channel to manage challenges to central government rule because it is a peaceful and routine way of maintaining the status quo and imposing regime decisions (such the allocation of the local government budget). Finally, I argue that in a context such as Islamic Iran, where ideological contestation is a marked feature of the regime and its relationships with political opponents, regimes will adopt decentralization reforms only if the support for decentralization by the main ideological camps converges or at least overlaps, although each camp will justify their support differently. Contestation over electoral institutions, national and subnational, then, cannot be explained adequately by referring to only the economic motives of actors as proposed by some neo-institutionalist approaches; rather, conflict over institutionalization will most likely in these cases also reflect ideological commitments of social forces. 
Taken together, these factors demonstrate the connections between local elections, integration through participation, and centralized state-building. Focusing on two dimensions of the regime's motivation for introducing local elections, and regime control of the institutions of local governance, I illustrate these factors through an analysis of political decentralization under the IRI. Highlighting the role of ideological contention, my thesis is that the competition between three societal projects shapes the evolution of local government and central-local relations in Iran since 1979: Islamicization, developmentalism, and democratization. Yet once in operation, the regime has effectively used the legal framework to control and channel local electoral institutions, just as it has with its national counterparts, blocking them from becoming an arena of local power able to compete and influence government bureaucracy, as well as challenge the Islamist limits of political life. I demonstrate these claims through an analysis of three arenas of contention at the local level: the scope of political participation, the degree of legislative authority, and the degree of fiscal authority.

\section{Four actors, three projects}

In this section I briefly describe the key social and political actors involved with the political decentralization reform (I discuss the societal projects of these groups in Tajbakhsh 2019). The ruling (or velayi) Islamists are the core supporters of the current regime, espousing a maximalist interpretation of the velayat faqih principle of clerical rule and the thoroughgoing islamicization of Iranian society; this group - clerical, lay and military - dominates the core theocratic institutions of the regime including most notably the office of the Supreme Leader, the Guardian Council, the Assembly of Experts but it also includes the armed forces and several political parties. The second group were the Islamic reformists parties and their supporters, promoting a program of political liberalization and democratization, forming the base of the Khatami $2^{\text {nd }}$ Khordad movement that won the 1997 Presidential elections, the 1999 inaugural local council elections and the $20006^{\text {th }}$ parliamentary elections; this group was represented by the parties such as The Participation Front (jebhe-ye mosharekat) and The Organization of the Mojahedin of the Islamic Revolution of Iran (Sazman-e Mojahedin-e Enqelab-e Islami-ye Iran) (Kadivar 2013). Finally, the developmentalist agenda was promoted by two actors. The civil servants and apolitical technocratic experts in the government bureaucracy and state planning agencies most notably in the Management and Planning Organization (MPO), Interior Ministry and other key ministries as well as universities; and the developmentalist Islamist parties ("moderates") led most prominently by The Executives of Construction of Iran Party. ${ }^{6}$

\section{Motivations for Creating elected local government in Iran}

The new constitution ratified in the fall of 1979 contained several articles concerning the place of elected local councils in the national administrative framework. Yet it was not until over a decade later during the post-Iran-Iraq war reconstruction period that the parliament took up the matter of political decentralization seriously. In the first half of the 1990s, pressures caused by urbanization, population growth, and lack of employment opportunities combined with crude forms of urban management involving

\footnotetext{
${ }^{6}$ See the entry Political Parties for some information (The Iran Social Science Data Portal n.d.).
} 
ruthless slum clearance policies provoked urban riots in several major cities that continued over several years. This impelled fourth Islamic Majlis (1992-1996) whose majority was elected in significant part to address the severe economic problems facing the country (Sarabi 1994) to propose a new law establishing elected councils to oversee the work of the municipalities. Building on the $1^{\text {st }}$ Dev Plan (proposed by the Rafsanjani government and approved by parliament in 1990) calling for boosting municipal revenues through local economic growth, the privatization of some services, and for greater local participation in the implementation of government services, the draft proposed decentralizing some functions of public administration to local government and to transform mayors from appointees of the central government to being accountable to a directly elected local council. They hoped in this way to address the unmet needs in cities and towns and to innovate new institutions which could respond more effectively to the widespread dissatisfaction of the burgeoning urban populations with centrally appointed mayors. ${ }^{7}$ For both the government and the parliament, improving efficiency of public management while at the same time assuaging local grievances, implied formalizing local electoral participation. They proposed to do this by creating a new tier of elected local councils a quite significant expansion of the state's electoral machinery. The majority of deputies in the fourth Majlis were from the "traditionalist right-wing" but were at the same time supportive of the pragmatic economic development agenda of the Rafsanjani government (Baktiari 1996). The Association's slogan was "obedience to the Supreme Leader and support to President Rafsanjani." Against the backdrop of widespread and persistent urban protests, the decentralization bill was introduced in 1992 by a cleric and member of the Combatant Clergy Association. This group were regime insiders: the chair of the parliamentary committee overseeing the bill was a stalwart of the revolution having previously held the post of chief of the "ideological correctness" office (aghidati) of the army. Expanding the space for political contestation was obviously not conceived to be a liberalizing challenge to the ruling regime. The Majlis approved the first local council law and after revising it to address several minor objections raised by the Guardian Council, passed it into law in 1996. The decentralization reform was thus initiated by the top political leadership and not by any organized pressure from below.

The provenance of the local council law is significant in light of the way it later became mistakenly associated uniquely with the democratizing agenda of the reformists. In fact, the reformists leading the 1997 Khatami administration took up the baton of this legislative achievement, raised the elected local councils to a central plank of their reform program, and pushed for implementing countrywide local elections. The new administration's decentralization reforms gained the cautious approval of the Supreme Leader and the Guardian Council, ${ }^{8}$ and dovetailed with the developmentalist agenda of

\footnotetext{
$738 \%$ of urban residents were highly dissatisfied with the performance of the mayor and municipality, according to a survey conducted by the government (Majlis Proceedings 1994, p. 27).

${ }^{8}$ In a 2017 oral history interview, the deputy Minister in charge of local government in the Khatami administration, M. Tajzadeh (2017), explained that Ayatollah Khamenei, the Supreme Leader, "told me two things when I became deputy minister: do not touch the shura; and that the choice of Provincial Governor (ostandar) of Mashhad and Khorasan have to be consensually agreed with Tabarsi and Mazaheri. Hashemi agreed with Khamenei on the basis of the argument that the council system would disrupt the administrative decisionmaking system of the country". Tajzadeh thus avers that the hesitation on the part of the country's leadership about establishing elected local government stemmed more from managerial than political concerns.
} 
the technocratic elites, both in the central government planning agencies and in the new moderate political faction in Parliament headed by the prominent Mayor of Tehran. Local elections were held throughout the entire country in February 1999 for Islamic city and village councils (shoray-e eslami shahr va roosta). This "big bang" reform was conducted peacefully and with a high degree of consensus at the national level.

This was no doubt part of a broader shift towards a developmentalist orientation by a regime forced to concede that economic growth and expert knowledge, hitherto spurned as anti-revolutionary, was necessary for war reconstruction and for paying for expanding social benefits (Harris 2017). Although the justifications for introducing the law for elected local government did invoke the importance of people's electoral participation as a way to enhance the legitimacy - and it was hoped the efficacy - of local government, it is important to emphasize that parliament was initially motivated neither by the goals of democratization and civil society development, nor was prodded to respond to local bottom-up demands for greater representation and voice, in contrast for example to that campaigns for provincehood had in fact mobilized local actors (I discuss the relevance of this case in the conclusion). Only later did the elected local councils come to be seen as part of the reformists' challenge to the regime's concentration of power.

\section{Actors perceptions of elected councils}

Each of the four actors had a different motivation for supporting the shura rooted in their perception of how these institutions would advance their societal project. The velayi Islamists viewed the local councils as a religiously sanctioned institution for organizing populist forms of urban participation within Islamist bounds - no doubt hoping to replicate in urban areas the work of the Islamic Rural Councils of the previous decade which had acted as "the executive arm of the state and the propagator of the culture of the Islamic Revolution in villages". ${ }^{9}$ The developmental Islamists and the apolitical technocrats saw political decentralization as the means of improving the administration of local areas by enhancing the legitimacy and responsiveness of local officials to the welfare and economic needs of far flung localities. ${ }^{10}$ The reformists' goal was to fill the new institutional vessels of local government with democratic content so as to strengthen the link between civil society and electoral participation at local levels. Together with the growth of civic associations, they hoped in this way to democratize state-society relations by shifting the center gravity of the polity from the central state institutions controlled by the clerical elite and their lay allies to empowered plural electoral and civil society institutions (Kamrava 2001).

Having discussed the motivations for introducing local elections, in the next section I describe the way the regime manages and controls constrains the autonomy and power of local elected institutions once they are in operation and channels their activities in ways that reinforce regime priorities. I focus on three arenas of contention at the local

\footnotetext{
Tajzadeh does not explain his decision to proceed with the council reforms despite the Supreme Leader's warnings.

9 Ettela'at, 20 Farvardin, 1363, cited in Arjomand 1989, p. 242 note 36.

${ }^{10}$ In a 2011 interview, Karbaschi, the head of the technocratic developmentalist party (Kargozaran), explained that they believed the best path to political development was through economic development.
} 
level: the scope of political participation, the degree of fiscal authority, the degree of legislative authority.

\section{Three Arenas of Contention}

\subsection{Scope of Political Participation}

First, I examine three features of the space of local politics: the scope of political participation, the role of civic associations in local governance, and the place of religious minorities in local politics.

Political Participation. One way in which the regime regulates the scope of local political electoral participation is through the process of qualifying candidates for elections. This follows the approach used for national elections with a few exceptions. Disqualifications can be distinguished in relation to three groups. The first are political forces that are illegal, namely all groups that fall outside the ideological and religious boundaries of the regime. These include secular, monarchical, or communist parties; those advocating eliminating the clerical establishment's privileged position over the levers of decisionmaking power; those groups or individuals calling for a nonhostile relationship with Israel and the United States; and generally those opposed to the principle of velayat faqih in form and in substance. These groups are not permitted to compete in elections at any level.

The second group are quasi-banned political parties and factions. The most notable are the two main reformists political parties, Participation Front (jebhe mosharekat) and Mojahedin of the Islamic Revolution of Iran Organization (mojahedin enghelab), which after the "Green movement" uprising in 2009 have ceased to operate, even though the legal niceties of the suspension of their permits have not been formally concluded. Two other significant groups banned since the 1960s are the Religious-Nationalists (mellimazhabi) and Freedom Movement of Iran (nehzat Azadi). One notable exception was in the second city council elections of 2003, when the reformists in charge of approving candidates at the Ministry of Interior, many of whom were members of the Participation Front (jebhe mosharekat), permitted members of the latter two parties to stand as candidates for local races. To this day the reformist are proud of presiding over what they call "the freest elections" since the revolution primarily for this reason. This unprecedented move, which was not repeated, caused a furor and none of the controversial candidates were elected. In fact, all the reformists suffered a crushing defeat in the local elections in many parts of the country. In Tehran, with less than 5 percent voter turnout (essentially a boycott by disgruntled middle class urbanites disappointed in the performance of the reformists who dominated the first council), the local council was won by a new so-called "neo-conservative" faction headed by M. Ahmadinejad, who became Mayor and then went on to be the controversial President presiding over the unwinding of the reform movement, culminating in the 2009 political crisis.

The third group are those disqualified through the formal vetting process. The procedural method of evaluating candidates is described in the local council election law. For city elections, the responsibility for ensuring the qualifications of candidates rests with the county level (shahrestan) executive electoral oversight committee (hayat 
ejraie shahrestan), which is chaired by the county governor (farmandar), working under and reporting to the parliamentary electoral supervisor committee (hayat markazi nezarat) and the provincial level executive electoral oversight committee (hayat ostan). Supposedly to ensure objectivity and prevent bias, the law stipulates that the electoral committee must request information on each candidate from four sources: the Judiciary, the Intelligence Ministry, the Police, and the civil registration office.

This formal procedural process can be divided into a political and an apolitical administrative dimension. The vast majority of candidates are weeded out because they lack the minimum qualifications (age, education, past military service, and so on), but the unfortunate absence of comprehensive data on who is disqualified and for what reasons prevents a rigorous analysis. Where political parties are poorly institutionalized, such as in smaller towns, so-called independent candidates proliferate because they do not go through the organizational discipline of being selected by parties. At the same time, reformists have always highlighted the fact that unlike national elections, candidates for local office are not vetted by the Guardian Council through "approbationary" (estesvabi) supervision (Arjomand 2012, p. 43). The reformers insist that in the absence of this instrument of political control to sideline opposition politicians, the procedural method of approving candidates provides greater scope for political forces to compete in local politics. The difference in method between the procedural and approbationary methods concerns the burden of proof. The Guardian Council's criteria entails "proving" that one is a good Islamic citizen (eejabi), whereas the procedural method (salbi) only requires the candidates not to fall below specified minimum requirements, such as not having a record of criminal conviction or the minimum age. However, this way of contrasting the methods of the Guardian Council with the parliamentary committee underestimates the fact that all laws in Iran today, no matter who is in charge, embody similar substantive criteria. Thus, all candidates are required to pass a religious test and a loyalty test: They must have belief and commitment to Islam and to the Absolute Vali Faqih and must express loyalty to the constitution of the Islamic Republic of Iran. ${ }^{11}$ In fact, one reason for the anomalous absence of Guardian Council vetting of local election candidates is simply a lack of organizational capacity. The Guardian Council itself has admitted that it lacks the necessary staff to review the hundreds of thousands of candidates for local office, which was one of the motivations for the Guardian Council to explore the idea of establishing provincial-level offices. However, the fact remains that even in the absence of the Guardian Council's direct involvement, the current laws are quite sufficient in most cases to ensure adherence to the norms acceptable to the ruling velayi Islamists. The institution responsible for reviewing qualifications is less significant than the criteria for acceptability. A parliamentary committee can enforce strict interpretations of the religious and loyalty tests just as well as the Guardian Council.

In light of these considerations, the experience of the last two decades indicates that with respect to the formal procedure reviewed above, there have not been widespread political disqualifications at the local level over the five rounds of local elections since 1999. Because the entire process is ultimately supervised by the parliamentary electoral supervisory committee (hayat markazi nezarat), the composition of parliamentary

\footnotetext{
ج -اعتقاد و التزام عملى به اسلام و ولايت مطلقه فقيه .د- ابراز وفاداري به قانون اساسى جمهوري اسلامى ايران..11
} 
deputies may impact the ultimate decisions of the provincial-level electoral supervisory committees, particularly in sensitive cases. This does not appear to have been determinative as a general pattern, though. The experience in Tehran is illustrative. In the first local elections in 1999, the chair of the parliamentary committee (the same conservative deputy in the fourth Majlis, who had sponsored the legislation for establishing elected local councils five years earlier) asserted that he would only qualify a number of well-known reformists in Tehran if they restated their allegiance to the velayat faqih in writing! (Avaleen dore-ye entekhabat, n.d.) They didn't comply (as far as I know), but the reformists succeeded in dominating the local council despite such highlevel opposition. (Whether the assassination attempt soon after on the leading reformist member was in any way related to this push back to reformists' local electoral successes can only be a matter of speculation). During the second Khatami administration, the democratic reformist Islamists in charge at the Ministry of Interior took the bold step of approving members of the two quasi-banned political parties mentioned earlier to run for local office. In the third round of elections in 2006, at the height of the Ahmadinejad presidency, four prominent reformists won seats to the Tehran city council. The third council was chaired by a conservative Ahmadinejad ally and, as members of the minority party, the reformists were kept out of leadership roles. Within the bounds defined by the Islamic Republic this all sounds rather like normal politics. During the fourth round of elections in 2013, the pall of the 2009 sedition (as the regime calls the Green movement protests) still hung heavily over all candidates. Two well-known reformist incumbents who had come out in support of the Greens and had publicly criticized the regime's policy of jamming satellite signals (ostensibly for causing health problems) were in fact disqualified. Yet the fifth-round elections in 2017 were swept by moderate reformists partly because a large number of democrat reformists had been tried and/or convicted after the 2009 protests and were now sidelined and not permitted to stand as candidates. Just to make sure, a senior member of the Judiciary announced that it was his duty to intervene and override any candidates that had been mistakenly approved if they had been supporters of the sedition of 2009 in any way (Esmaili 2017).

The scope of participation in local as in national politics remains an important arena of contestation. Qualifying candidates remains a tool of political control, even if it doesn't always have to be wielded explicitly. At the same time, the robust institutionalization of elections under the Islamic Republic means that, as a general rule, the selection process has been effective before the stage at which explicit candidate evaluation takes place.

Civic Associations. From their inception, elected local governments have been at the forefront of supporting associations in what, in a sociological but not juridical sense, can be called civil society in Iran. ${ }^{12}$ This author was involved in organizing one of the first international workshops on cooperation between city councils and civic associations in Iran (Khatam 2000). The reformists in power in the local councils and in the Parliament encouraged and supported a wide range of associations, including those with opposing political views (such as velayi Islamic students' associations), which they saw as necessary for the development of an independent civil society sphere. Conservatives, by contrast, adopted a narrower and security-based approach, discouraging

\footnotetext{
12 Some Iran analysts have questioned the relevance of the liberal concept of "civil society" as derived from Western experience for the Iranian case (Arjomand 2000).
} 
nongovernmental organizations (NGOs) that could foster oppositional points of views and agendas. Thus, when reformists (moderate and democratic) controlled the municipality in the early 2000s, many associations were permitted to proliferate, often with the assistance of municipal resources. However, because NGOs were a natural place for secular and radical opponents of the regime to gather and mobilize, they became areas of concern for the regime. (Ultimately, they were dismantled under the conservative-controlled councils, who after 2004 pursued what they called an alternative "mosque-based" (masjid-mehvar) and neighborhood-based civic association strategy.) Similarly, the urban planners in the Tehran municipality pioneered a neighborhoodbased, deliberative planning strategy to extend the scope of participation in urban governance in order to embrace cooperation between the local government and civic society through the use of neighborhood councils (shorayari) in local planning. This initiated a tug of war over which institution - the elected local council or the Ministry of Interior - should have primary control over the advisory neighborhood councils. This no doubt reflects the recognition of the potential significance of these neighborhood councils in mobilizing support for political programs at a granular level.

Civil society is an object of concern for the regime for both principled as well as securityrelated reasons. Because the monistic political theory motivating the Islamic Republic does not easily accommodate the dualistic view of civil society as a sphere apart from the state, the regime has struggled since its inception with what to do with NGOs. A regulation defining the Islamists' version of NGOs called "people's institutions" (sazman mardom nahad) was passed in 2016; debates over whether to draft a full-fledged law remain unresolved. The regime's anxieties about an uncoerced sphere of associational life - the classic definition of civil society - is not motivated solely by the goal of preventing the emergence of political opposition. It is also a principled consequence of the ideological commitments of a non-secular, non-liberal state. Ayatollah Javadi-Amoli (2010, p. 411) and Ayatollah Misbah Yazdi (2001, p. 26), two of the leading clerics writing on Islamic political theory in Iran, while recognizing a place for associations in the public sphere, both ultimately reject any conception of civil society contradicting Islamic values (as enshrined in the constitution), such as the promotion of secular values, equality of citizenship, or a sphere of conscience falling outside the supervision of the clerical authorities. Within these bounds, the possibility of civic associations including neighborhood associations to collaborate with local government in setting the agenda and in monitoring remains a minor if important element in defining the scope of participation in Iran.

What about Sharia? The Niknam Controversy. Since the inception of elected local government in 1999, the Islamization project has been conspicuous by its relative indifference to local matters (apart, of course, from the fact that all aspects of life under the Islamic Republic of Iran must ultimately conform to Islamic law and values). However, the Guardian Council has intervened in an unprecedented way to remove any ambiguities that some may have believed existed regarding the specifically Islamic nature of local government in the last few years. In 2016 the council law was amended to underline that the Guardian Council is authorized "at any point in time [i.e. even after a law has been in force] to exercise their supervisory powers regarding the conformance of local government laws with the sharia." A year later this "reserve" power was dramatically illustrated when the Guardian Council removed an elected local councilor, 
Sepanta Niknam, on the express grounds that he was a non-Muslim. The case in point concerned the sole Zoroastrian member of the Yazd city council (Yazd is a spiritual home for that religion), who was serving his second four-year term since 2013. The Guardian Council reinterpreted article 26(1) of the Local Council Law, hitherto read as permitting officially recognized minorities (Jews, Christians, and Zoroastrians) to run for office and which had been on the books for almost two decades. The Guardian Council declared that henceforth religious minorities were forbidden to be elected local deputies to a decision-making body in any place where the majority population was Muslim. The only exception was where the non-Muslims formed a majority of an area or if the minority representatives were restricted to deciding on matters exclusively concerning the minority community. The jurisprudence on this matter rested on a well-known principle of figh,

$$
\text { نفى سبيل للكافرين على المسلمين }
$$

which asserts that it is prohibited for non-Muslims to have influence or decision-making authority over Muslims. ${ }^{13}$ The Guardian Council's reasoning also derived from an opinion expressed by Ayatollah Khomeini in a 1979 speech - not a legal ruling declaring that only Muslims could be elected to local government offices. The Guardian Council's decision caused some minor controversy both among some establishment politicians as well as theologians who (as to be expected from seasoned hermeneuticists) contested almost all the critical points of interpretation. ${ }^{14}$ The (Muslim) head of Yazd city council publicly expressed his frustration and disagreement; Ayatollah Sane'i, a well know cleric aligned with the reformist, rejected the Guardian Council ruling; and Ayatollah Sistani, perhaps the most influential cleric in the Shia world, had already ruled that this principle does not prohibit Muslims using the skills of non-Muslims in public affairs. Despite these objections, the Guardian Council emphatically asserted that it is the final and only arbiter of questions of sharia and its ruling is the law of the land and must be enforced. To prevent any controversy from arising again, a senior member of the Guardian Council, Mohammad Yazdi, proposed that the Guardian Council's representatives on the provincial oversight committee (hayat tatbeeq, discussed below) should be more proactive in disqualifying candidates in the future. (Yazdi did not explain how this ruling was consistent with having religious minorities represented in the national Parliament) The Guardian Council's decision signals its intention to prevent any ambiguities concerning local institutions, which, as we have seen, allowed them to be used to bring in controversial political forces in "under the radar," as with the two quasi-banned parties in the second local council elections.

Because of the Majlis's opposition to the Guardian Council's ruling, a deadlock emerged that led to the case being sent for final adjudication to the Expediency Assembly (Majma), which ruled against the Guardian Council and reinstated the Zoroastrian city council member.

\footnotetext{
${ }^{13}$ Based on the Quranic verse: ولن يجعل الله للكافرين على المؤمنين سبيلا (4:141).

${ }^{14}$ Including whether the verse applies to this world or only to the afterlife, as the context of the whole verse seems to suggest; whether kafir should be equated with all non-Muslims; whether the verse concerns only kafar-ish behavior not kafir persons; and whether the power of an elected representative (vakil) counts as an instance of domination (solte) and injurious influence (سلطه، نفوذ و استيلاى).
} 
The Expediency Assembly is the executive arm of the Supreme Leader's Office and is charged with resolving conflicts between the Guardian Council and the Majlis on the basis of "state interest" (maslahat). In many instances over the last four decades, this has meant contradicting the Sharia as interpreted by the Guardian Council. The tension between Sharia and maslahat highlights the ambiguity concerning the real operative sources of legitimacy and authority underpinning the state, namely between Islamic principles versus the authoritarian power of the ruling elites. From one perspective, employing the maslahat principle of "state interest" undermines Islamic law (sharia); this is because the Supreme Leader (represented by the Expediency Assembly) can void decisions made by the Guardian Council, which is by Iranian law the sole authority for determining what is and isn't consistent with the Sharia (Art. 4 of the constitution). On the other hand, if maslahat is itself a desideratum for proper Islamic jurisprudence, then the apparent tension between the EC and the Guardian Council is transformed (Schirazi 1998, pp. 233-244). What remains is merely the conflict between two different interpretations of Sharia.

The Majma has not published its reasoning concerning the constitutionality of its decision about the legality of religious minorities in local government. This is unfortunate because it neither contributes to the jurisprudence in this area nor sheds light on the broader implications for local government in general. For example, does the Majma's decision extend to all other religious minorities and to all other geographical locations? Or is it restricted to this one candidate, in this one town, and at this one time? It is not possible draw inferences regarding these questions at this time. One might be tempted to conclude, therefore, that the decision of the Majma to side with the Parliament and against the Guardian Council was based on political and social rather than jurisprudential grounds.

In fact, contrary to what might be expected from a theocratic state, the substantive objectives of the decentralization debate in Iran tend to be removed from any direct concerns with religion as such. As explained above, the central concern has been enhancing state capacity for improved public sector management; this is common to many regimes and societal contexts quite distinct from the Iranian case. Thus, it may be that focusing on the question of the legal basis of local autonomy in terms of its democratic potential (and its potential to challenge the dominant interpretation of Islamic law) misleads us into overemphasizing the question of local democracy and underestimating the managerial challenges facing any kind of state. From the perspective of a country facing the apparently non-ideological challenge of managing its public resources to best meet its basic material needs, it is perhaps worth recalling the famous maxim that "the most important political distinction among countries concerns not their form of government but their degree of government." Still, this assumption might be acceptable to the technocrats (and in the case of decentralization, the velayi Islamists), who are confident that the well-spring of society's norms remains secure in other domains unrelated to decentralization (such as socialization through the family and cultural sphere into religious and communal traditions). On the other hand, such an assumption would be unacceptable to the reformists and democratic Islamists; they would not be satisfied with assessing decentralization in terms of merely administrative or economic efficiency. For them, the project of democratization was (and remains) integrally tied to the search for a more robust model of local democracy, which the 
reformists evidently did not consider to be incompatible with the revisionist view of Islamic law and practice that they espoused.

\subsection{Degree of Local Fiscal Authority}

Local governments in Iran are accorded, in theory, a limited measure of financial autonomy, capacity, and responsibility on both the revenue and the expenditure side. Using the standard quantitative measure (municipal expenditures as a proportion of GDP), local fiscal autonomy in Iran is very low - in relative terms it is less than 5\% (Tajbakhsh 2006). (This is comparable to the rest of the Middle East but contrasts with the average of about $20 \%$ for all unitary countries and $50 \%$ for all federal countries). ${ }^{15}$ The elected local council is given the authority to administer a range of local sources of revenue defined by the central government and national law; local expenditures are relatively lightly restricted to ensure that a minimum $40 \%$ of the total budget is allocated to capital expenditures. In principle this gives the council a degree of flexibility in determining how local priorities are reflected and where and on what local resources are spent.

The economics literature holds that the core of efficient fiscal decentralization requires local governments to possess the authority to finance local services from their own local sources "at the margin" (Bird and Vaillancourt 1998, p. 13). ${ }^{16}$ The important implication for local democracy is that even where local government derives almost its entire budget from the central government, as long as these transfers are fixed and cannot be changed in a single electoral cycle, the local government can still be perfectly accountable to its residents or even to central government. Of course, accountability per se does not necessarily entail democratic accountability. Local governments are democratic to the extent that the local resident preferences are reflected in budget choices, that costs and benefits of decisions are transparent, and that all those affected have an opportunity to influence the decision.

In this section I explore the scope of fiscal authority in Iran through an analysis of the jurisprudence of administrative law applied to local government. Relying on various laws giving them authority to identify and collect some local sources of revenue, elected local councils throughout the country have sought repeatedly to innovate and extend their prerogatives on this legal basis. The established process for legalizing taxes is as follows. The Mayor's office must propose new taxes to the city council, who then send the approved list of local taxes to the provincial governor's office, who in turn has two weeks to object (or not). (This is also related to the review of local council legislation described in more detail in the next section.) According to one interpretation, the city council is forbidden to propose new taxes independently of the Mayor's office

\footnotetext{
15 Comparative data is from OECD/UCLG 2016, p. 20. The measures used here should be treated with caution; for instance, municipal expenditures as a proportion of GDP for China is over $80 \%$, but local governments there possess very little autonomy and act as mere spending agents for the central government. The metric is nonetheless a useful indicator of the relative significance of the local government sector. For a more speculative ranking of countries including Iran see Ivanyna and Shah 2012.

16 "At the margin" means that for the last "unit" of the service supplied, the welfare benefit to society just matches its cost. This is easy to conceptualize (for the economist) but hard to measure in practice. This is because local action to alter revenues or expenditures will directly impact outcomes, and given conditions such as transparency in information and outcomes, this is the necessary condition for accountability.
} 
(Mousazadeh and Sohrablu 1394). ${ }^{17}$ The law specifies an arbitration process in case the council wishes to appeal. ${ }^{18}$ The approved list of local taxes (ta'refey-e avarez mahalli shahrdari) are then published - and publicly available on most Provincial Governor's websites - and are immediately legally enforceable; the taxes are then collected by the municipal administration as the executive arm of local government.

Over the last decade the volume of complaints brought against municipalities by individuals, businesses, and central government agencies contesting the legality of local taxes innovated by the municipalities has increased markedly. The Court of Administrative Justice (divan-e edalat edari, henceforth the Court) arbitrates complaints brought against municipalities. Although I have been unable to complete a comprehensive assessment of all cases considered by the Court relating to local government, it appears that the majority of cases concern the legality of the new sources of revenues. From the sample of cases I have been able to review, it seems the Court has consistently ruled against the municipality, striking down and voiding the decisions of the local council, which in most cases has already passed the review process in the provincial governor's office without objection.

A brief look at two cases gives a sense of the trends in center-local fiscal relations. The first case demonstrates that the exercise of administrative law in the area of local government law has not emerged (yet) as an arena for jurisprudence to address the broader political economy implications of political and fiscal decentralization. The second case shows the way in which the management of land-use, typically an immediate concern of local government, is controlled by the central government. Both cases carry implications for the ability of local government to effectively manage local resources in ways that can foster a local constituency for effective government. I take this to be at the heart of a realistic project of local democracy.

In 2014 Kerman City Council passed a local law imposing a 10\% tax on all ticket sales for cultural events in the city, including cinemas, concerts, and other public ceremonies. The plaintiff, an owner of a private cinema, first argued that because cultural institutions are "producers of auditory effects," they are governed by the national tax law, which forbids local government from imposing taxes on "products" (toleedaat) (Court of Administrative Justice 2016). ${ }^{19}$ Second, he argued that these products are "public goods" and thus should be exempt from such taxes. The complaints raised two separate issues, the what and who: Which level of government should have authority over which type of tax. The City Council argued that the law has imposed upon the local council the "essential duty" (vazifeye zaati) to secure the revenues necessary and appropriate to address the needs of the city. The City Council emphasized the diligence with which they had discharged their responsibility: The tax proposal was approved only after full deliberation in the council, the council drew on outside legal and financial experts, and

\footnotetext{
17 اب ابر اهيم موسيز اده and علي سهر ابلو, 'صلاحيت وضع عو ارض و اصول حاكم بر آن در بُرنو آراى(Legal Taxing Authority in Iran)

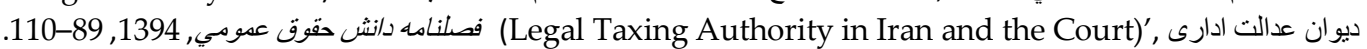
18 This recalls the significance of the distinction between the early Belgian and French models of local government. In the French case, the Mayor had considerable autonomy from the locally elected representatives, which allowed the central government in Paris to rule localities directly through the mayors. Whereas in Belgian local government, the Mayor had to negotiate with the aldermen. "In the final analysis, prefects monopolized the power to act directly or through their appointed mayors" (Woloch 1994, p. 430). 19 Under Art. 50 and 52 of the 2008 (1382) Value Added Tax (VAT) Law قانون ماليات بر ارزش افزوده
} 
the proposal suffered no objections from the Governor (ostandar). Citing an earlier Court ruling that "since the law has required municipalities to be financially self-sufficient (khod-gardan), creating new sources of local revenue to finance urban services is not forbidden by law," the city council insisted that their taxes were consistent with that opinion. The council's argument also reached into broader policy implications in an interesting way. It is not right, Kerman City claimed, that the local government should be restricted to obtaining revenues only from residential properties or from small shops; if banks or large shops, which demand the greatest amount of resources in urban services, are exempted from paying local taxes (referring to other cases before the Court), the tax burden will fall unfairly on other sectors such as homeowners. Kerman City concluded that if the Court voided this local tax (i.e., ruled in favor of the plaintiff) it would pose serious obstacles for all municipalities to provide services to their residents (shahrvandan). As a result, the administration of the municipalities throughout the entire country would suffer. The Court rejected these arguments and struck down Kerman City's new tax. Ignoring the thrust of the City's argument, as in most other such cases, the Court argued straightforwardly that the national V.A.T tax law (Art. 50) prohibits local government from imposing new taxes; and that a local tax on concerts and public ceremonies falls under the category of taxes reserved for the central government. ${ }^{20}$

The second case concerned a new local tax introduced as part of the 2007 Tehran Master Plan. Although all city master plans in Iran are the responsibility of the Ministry of Housing and Urban Development (MHUD), ${ }^{21}$ for the first time the Tehran city council was permitted to participate in some aspects of the Tehran Plan preparation but was restricted to only an advisory, non-voting role. The final document included a regulation ${ }^{22}$ imposing a tax (avarez) on certain land-use changes resulting from the new 2007 plan; however, this regulation was apparently ratified only by the Tehran City Council and not by the central government agency. The regulation was reaffirmed in 2010 by another city council decision, which specified the revised schedule of charges in connection with this new tax. In response to the complaint of a property owner, the Court (2017) ruled that the new source of revenue was illegal, based on restrictions on local government powers in the areas of land-use management and taxing authority. First, the Court clarified that only the agency explicitly specified within the Ministry of Housing and Urban Development ${ }^{23}$ has the competence to decide on land-use changes; ${ }^{24}$ the Court pointed out that the City Council Law does not explicitly mention land-use changes as one of the competencies of the elected local council. Second, regarding local finances, the Court argued that it is national tax law that determines all local charges, ${ }^{25}$ consequently, local governments are not entitled to impose new charges on services

\footnotetext{
برقر ارى عو ارض به در آمدهاى مأخذ محاسبه ماليات 20

${ }^{21}$ Specifically, the Supreme Council of Urban Planning and Architecture (SCUPA), shora aali shahrsazi part of the Ministry of Housing and Urban Development.

22 Section 1 of Appendix 4.

${ }^{23}$ The so-called Art. 5 Commission of the SCUPA Law. The Art. 5 Commission consists of the Chair (only in Tehran), the Mayor, and representatives of several ministries; two non-voting members: Head of City Council relevant to the case and Iran Construction Engineering Org. For all cities outside Tehran, the Art. 5 commission is chaired by the Provincial Governor, the Mayor is a voting member, and the city council representative is non-voting.

1388 قانون اصلاح ماده ( 5) قانون تأسبس شور اي عالى شهرسازي و معماري اير ان 24 (Art. 174)

25 The Fifth Five Year Development Plan Law (Art. 174) specifies that it is the VAT Tax Law.
} 
related to land-use or permitted to make land-use changes. Restrictions on the ability of locally representative institutions to manage land is significant. Because land is the only factor of production capable of being controlled by local governments (unlike capital and labor, which typically cannot be), its management is critical to the scope of local control.

The Court of Administrative Justice has ruled on numerous such cases. In December 2017, no longer willing to consider the growing volume of such complaints on a case-bycase basis, the Court requested that the Ministry of Interior issue a directive to all Governors (ostandar) instructing them to block municipalities from passing any more local legislation with respect to illegal taxes. The Court also informed the provincial office of the judiciary ${ }^{26}$ to instruct its representatives on the "joint local government committee" (hayat tatbeeq, described below) to block such illegal local decisions when they review local legislation. As the Court and Ministry of Interior explained, the volume of complaints was wasting the time of the Court.

Although this action might be understandable from a purely administrative standpoint, it does not help redress the fiscal double-bind in which local governments in Iran find themselves. The dominant narrative advanced by disgruntled municipalities is that they are locked into an "unsustainable" (na-payedar) and "unhealthy" (na-saalem) financial situation. They are "perversely controlled" by the central government, which simultaneously (1) prevents local governments from expanding the types of local taxes (the base), (2) prevents increases in the amount (derived from the rate) they are able to derive from the one major revenue sources that is permitted, namely the property tax, which results in a negligible contribution from this source; and (3) imposes expenditures responsibilities (unfunded mandates) on local governments. As a result, local governments are compelled to derive the majority of their income from selling building permits for new construction and for so-called increased "density sales" (furush tarakom) above the height or density levels fixed in the local development plans. They claim that this situation is not sustainable or healthy because it prevents stability in forecasting future revenues and is overly dependent on the unpredictable nature of the construction sector; worse still, it encourages non-transparent backroom deals between the municipality (especially in large cities) and private developers, encouraging corruption.

The significance of this situation, from the perspective of the reformists' project of advancing local democracy, is that the absence of local capacity for influencing land-use planning discourages and the limited local capacity to decide on money matters inhibits the growth of a local constituency for effective government (at any level of governance) because it makes the accountability of opaque institutions to residents harder to achieve. The assumption here is that if local governments lack what residents consider adequate power, they will refrain from participation. Over time, this will undermine the spontaneous motivation for social action and civic responsibility required for preserving the legitimacy of local institutions. ${ }^{27}$ It will also undermine the state's own objectives for

رؤساى كل دادكسترى هاى استان ها | 27

27 But it must immediately be said that greater local government capacity would not by itself necessarily guarantee such a local constituency, as some theorists of democratic "localism" assume. The experience of local government in China bears this out (Wu et al. 2007, Ang 2016, Distelhorst and Hou 2017). I believe the Chinese case forces us to assess the possibilities for local democracy in a country such as Iran with considerable skepticism. However, consideration of this point is beyond the scope of this paper. 
the effective and efficient output needed for the state-society bargain. State legitimacy then suffers with respect to both substantive and procedural criteria. This "modernization trap" is an old story. ${ }^{28}$

In light of the foregoing analysis, three general conclusions emerge about the way intergovernmental financial relations have shaped center-local relations. First, the analysis confirms the thesis that the expansion of the infrastructural power of the state can be a "two-way street" - the institutions through which the state penetrates society and territory can also empower society to express its demands back to the state. Thus, elected local governments in Iran have used the institutional and legal capacity given to them by the central government to test the limits of their autonomy (albeit in a very limited way) by passing local laws that identify new sources of revenue not explicitly envisioned in the statutes. Notwithstanding the fact that these efforts were generally unsuccessful, the ability of local government to appeal central government regulation demonstrates the potential of political decentralization to be a voice for local concerns as compared with a system of pure administrative decentralization lacking any such possibility of appeal. Of course, these appeals need not necessarily reflect local preferences; while they might be a measure of the responsiveness of local government officials to constituent demands, they might simply be local official's own interpretation of local needs without much local consultation. More worryingly, the appeals could also be an indication of local elite capture, where local officials seek to expand of their power and budgets in ways that are not aligned with local interests. Only empirical case analysis could determine the relative influence of these factors in any given city. ${ }^{29}$

Second, the evident institutionalization of the rule of administrative law confirms the thesis of the consolidated nature of the current Iranian regime. In this sense, state power under the Islamic Republic is not arbitrary, even if it does not conform to standards of Western liberal democracy. In the case of local finances, administrative law is wellorganized, clear, and transparent. Whatever else it is, it is generally not arbitrary or opaque. Also, within restricted limits, local finances are in principle open to a limited degree of contestation by societal interests.

Finally, the evidence establishes that administrative jurisprudence has consistently and coherently enforced the constitutional and legislative limits on local government, operating on the ultra vires principle that only authorized action is valid. At the same time, the rulings of the Court demonstrate almost no independence in the judicial determination of the scope of local government authority (i.e. over the question of whether or not the local agency is operating within its legal boundaries). This is a degree of discretion that in principle is consistent with the exercise of administrative law and would contribute to case law on this matter (Stack 2015). Moreover, analysis of the cases does not reveal any attempt by the Court to explore alternative frameworks for fiscal decentralization, such as the potential relevance of principles of subsidiarity

\footnotetext{
${ }^{28}$ Woloch's (1994, p. 149) observation about French localities in the early nineteenth century clearly identifies a general structural problem: "The heavy hand of the state 'stunted the growth of local civic responsibility' but also made it difficult for communes to meet the state's own objectives for output and administration." ${ }_{29}$ It is possible that the legal relationship of local government dependence on central government may, in practice, be consistent with de facto amounts of local power, which can be used to advance local interests against the central government. That power can then be used to advocate for greater legal authority for local government. This is often the case in the largest cities in Iran.
} 
incorporated into local government law. There does not seem to be a conceptual barrier to incorporating notions such as subsidiarity in Iran; in fact, several international cases show that subsidiarity can be consistent with a constitutional commitment to a unitary, centralized design of the state. ${ }^{30}$ Notwithstanding justified concerns that subsidiarity may conceal a covert legal monism, ${ }^{31}$ there is nothing in principle preventing the Iranian courts from exploring ways to elucidate, and perhaps even expand, the principles and justifications of decentralized authority within the current Iranian constitutional framework.

\subsection{Scope of Local Legislative Authority}

In previous sections I summarized the duties specified in the law for local councils and reviewed the restrictions imposed by national tax laws on the scope of local fiscal authority. Here I look briefly at two aspects concerning the scope of legislative authority, the changes in nature of legislative oversight over the last two decades and the current debate over-extending the range of policy areas over which the elected local government should have direct responsibility. I show that the legislative process is highly and effectively regulated in ways that simultaneously reinforce the centralization of the state in both the dimension of rationalization (state capacity) and in monopolization of power. This challenges views claiming that state institutions in Iran are weak (Brownlee 2007, p. 181). While trends in both these areas demonstrate relatively coherent approaches to intergovernmental relations they do so in ways that marginalize the role of elected local councils in local governance, privilege the administrative bureaucracy, and fail to achieve the collaboration between elected and appointed institutions that was one of the aims of political decentralization.

Many critics, including conservative local politicians, have complained that over the last two decades the central government and Parliament have consistently reduced local government authority both in the law and in practice. My review of the changes in legislative oversight of local government decisions by central government bodies does not show a marked recentralization of power in this area (as the critics contend). Instead, these changes demonstrate a move towards greater coherence of the state as a whole. Arguably, they may even lead to a potential increase in the capacity of local government in some areas. (In what follows I discuss only city governments, ignoring villages and rural counties.)

The legislative process is as follows. All the decisions of local councils must be sent for review to a three-member Conformance Committee (hayat tatbeeq) representing the government, the Judiciary, and the Provincial Council of Local Councils in that province. ${ }^{32}$ The committee evaluates local council decisions for conformity with national

\footnotetext{
30 Such as in Poland (Jackiewicz 2012).

${ }^{31}$ Jean Cohen (2012, p. 57) has drawn attention to this point in the context of world society, but as an analytical point it is applicable to center-local relations within a nation-state.

32 The Composition of the Conformance Committee (Hayat Tatbeeq) has three persons: a County Governor (Farmandar) (Chair), one judge appointed by the Head of Judiciary, and one representative from the Provincial Council of Local Councils (shoraye ostan) chosen by local council in question. The Provincial Council of Local Councils (shoraye ostan) and the County Council of Local Councils (shoraye shahrestan) are indirectly elected bodies selected from directly elected city and village councillors by the councils themselves. They have only an advisory and supervisory role, with no legislative authority.
} 
laws and regulations and ensures that they are consistent with the legal powers of local government. The Conformance Committee has two weeks to object. If there is no objection, the council's decisions become law. If there are objections, the council must either revise or appeal to an arbitration committee (hayat hal ekhtelaf), which must render a final decision within twenty days. ${ }^{33}$

Without a comprehensive empirical review of the record of all council decisions, it is difficult to make a complete analysis of this process or to assess the extent to which it has been employed as an instrument of political control or has contributed to a recentralization of power. Interestingly, it was the conservative former Chairman of Tehran City Council - closely aligned with the velayi Islamists - who complained bitterly that a "governmental mentality" has been the main obstacle to increasing the role of local governments throughout the country. Another conservative on the Tehran council also decried the Parliament's anti-decentralization bias as short-sighted; giving greater responsibility to local councils, he insisted, would demonstrate that the government values collective and public wisdom (kherad jami), would help fortify the bonds between society and state, and would contribute to national unity and social cohesion (Bayadi 2010).

Indeed, some recent changes appear to reflect the desire for greater rather than less local input into the decision-making process. A case in point is the rationale behind the creation of the Conformance Committee in 2016. Prior to that time, all decisions of local councils were reviewed only by the county governor (farmandar), who is usually perceived as representing the official and security branches of the central government. Advocates of expanding the oversight of local decisions from a single official to a threemember group argued that the county governor was ill-equipped to review local legislation, often acted arbitrarily, or simply failed to review matters on time (Majlis Proceedings 2016). This ineffectiveness resulted in a high volume of complaints against the councils, which could have been avoided, thereby alleviating the burden on the local judiciary and other decision-making bodies. Other supporters of the idea of creating a Conformance Committee explicitly argued that it was important to have a member of the Provincial Council of Local Councils on the review committee to defend and justify the local council's legislation. In this one respect, the direction of change (however minor) has been toward greater inclusiveness of the elected representative institutions, thereby strengthening local legislative authority somewhat.

Whether this change really does amount to the empowering of the elected institutions is debatable; in practice, the slightly increased role of elected councils in the oversight of local legislation is most likely outweighed by the weakening of the elected institutions in another more significant sphere of decision-making, namely the provincial-level planning committees. A Provincial Planning and Development Council (shoraye barname reezi va tosee ostan) in each province, which decides how, where, and on what the government's budget is spent, is designed primarily to coordinate line ministry offices with each other. Since the inception of elected local government, this council has included a token nod to the people's elected representatives - from the Parliament and

${ }^{33}$ Composition of the Central Arbitration Committee (responsible for cities above 200k population) includes representatives from the offices of the President, Minister of Interior, Court of Administrative Justice, the Attorney General, the Parliament, and the Provincial Council of Local Councils. 
from elected local councils - who sit as only as non-voting advisory members. Despite this marginal role, recent legislation devising the composition of the planning council weakens the already feeble influence of the elected institutions vis-à-vis the central government bureaucracy. This does not bode well for the project of local democracy, instead strengthening the project of centralized technocratic control over the local planning.

The available evidence shows that the intergovernmental design is highly regulated and designed to ensure maximum coherence and coordination between different parts of the governmental apparatus. This may amount to a system of checks and balances of sorts. While the top-heavy composition of the legislative oversight committees does not by itself imply a recentralization of power (or at least not much more centralized than it initially was), the picture that emerges when placed in the broader context of the relative influence in national planning (which, as we saw, tilts to the deconcentrated side) is still a relatively marginal role for elected local democratic forces in the intergovernmental system as a whole.

This reality is related to a second area of debate, namely whether the scope of decentralized responsibilities given to municipalities should be expanded. A common refrain from those seeking to deepen the democratic character of local government is that the reason local government is weak - and thus cannot fulfill its mission to act as the democratic representative for its residents - is that municipalities are restricted to an overly narrow range of responsibilities. Accordingly, it is a common refrain that elected representatives do not form a city council (i.e. a legislature for the entire city) but are merely the "municipality's council." These critics contend that locally elected representatives are mere adjuncts to the Mayor and are limited to overseeing the performance of the municipality. Instead, they proposed that the local councils should have control over all fundamental policy and services in their city and should be able to control, for example, local utilities, which are currently the responsibility of the several line ministries. Pressured no doubt more by the growing cadre of influential municipal officials, technocrats, and politicians eager to expand their power and access to resources than by advocates of local democracy (given that there are no legal lobbies for such a social force), a draft bill introducing "comprehensive urban management" is currently (as of this writing) being reviewed by the government and the Parliament. ${ }^{34}$ One version of the bill would decentralize many functions - from utilities to land planning - from the central government to local government and would also introduce directly elected Mayors in the largest cities.

In my view, proponents of local democracy will find these changes to be a mixed blessing. The fact is, the current law already gives the city council the right and the responsibility to oversee the entire municipal budget and local finances - something that lies at the heart of accountable government. The fact that this potential has not become a pressing concern for many residents, or that the local councils have been stymied when they have tried to scrutinize the financial dealings of local officials who are wellconnected members of the ruling elite, suggests that there is current potential that might, under favorable circumstances, be exploited. Expanding the range of functions of often over-burdened municipalities is unlikely by itself to advance the project of local

1393شهريور ماه ييش نويس لايحه قانونى مديريت شهري34. 
democracy. It is more likely to enhance the power of technocratic elites and nurture the growth of a class of local government politicians. The danger of local state capture rather than the blessing of responsive accountable local government is certainly present. This is certainly more likely in the case of the largest municipalities. Mayors of Tehran, for instance, have often succeeded in eluding the scrutiny and sanction of the Tehran Council by relying on their enormous de facto power. Giving these Mayors added independence by being directly elected would not strengthen the people's locally elected representatives unless the council has the capacity to hold the municipality to account and make good on its mandate to make local government accountable to the residents of their city. Dispersal of power without accountability does not strengthen democratic legitimacy; it can lead poorer local governance capacity and can facilitate political or elite capture (Khemani 2015, Mookherjee 2015).

\section{Conclusion}

States can be centralized in two qualitatively different ways. On the one hand, a state's capacity to accomplish things on behalf of society - its power to - depends on the rationalization of state administrative bureaucracy. On the other hand, a state's ability to dominate society, its power over civil society, depends on its monopolization of power disempowering alternative sources of authority. Political decentralization of the intergovernmental system plays an important role in shaping both forms of power. In this article, I have argued that the Islamic Republic of Iran created a new tier of elected local government in 1999 with two objectives in mind. It was compelled to increase the capacity of the state bureaucracy to respond to unmet infrastructural and service needs in urban and rural areas by making local administration more efficient and responsive; the government hit upon decentralization as a solution. At the same time, mounting widespread popular dissatisfaction with municipal management led the regime to seek ways to increase the legitimacy of municipal public officials through which it was implementing the state-led developmental agenda; locally elected councils directly selecting and supervising mayors transformed local state society relations, giving voice and representation to local populations for the first time. However, because the law confined electoral participation within the monistic assumptions of the ruling Islamist regime, it represented a process of monopolization of centralized power. Whereas the main actors involved in political decentralization reforms shared the goal of rationalizing state power and bureaucracy, the goal of increasing legitimacy of the new local institutions was the subject of ideological contention. Islamists, developmentalists, and democratizers competed to define the new local institutions, just as they were doing at the national level. But ultimately the alliance of ruling Islamists and developmentalists succeeded in integrating local electoral institutions into the broader electoral authoritarian theocracy defining the IRI as a whole.

In this paper I showed how the ruling regime has succeeded in maintaining control over newly empowered local institutions primarily through three legal mechanisms: tax laws restricting local fiscal capacity, administrative law constraining local legislative initiative, and electoral laws restricting political participation. The findings are largely consistent with the literature on political decentralization under nondemocratic conditions. This research has shown that in a wide range of cases the establishment and continuance of elected local government has not depended on bottom-up demands for 
greater voice and representation. At the same time Iran represents a rare case in which a major political actor - the reformist parties - did make political decentralization a central part of their democratization project; the fact that their agenda of using local government to spur the growth of an independent plural civil society did not ultimately prevail should not lead us to overlook the possibility that local elections can be framed as a contest between ideological orientations, including democratization. This is particularly likely in situations where an ideological regime confronts alternative ideological orientations, as is the case in Iran.

This paper's findings have implications also for the broader literature on state building and elections under the Islamic Republic. The experience of two decades of local elections in Iran is consistent with literature on authoritarian persistence; many studies of national elections show the successful assimilation of electoral forms of participation by the nondemocratic theocratic regime (Keshavarzian 2005, Tezcür 2012, Hashemi 2014). Other scholars contend that elections have been routinized and institutionalized under the IRI because they are an effective mechanism of regulating factional rivalry (Sarabi 1994, Baktiari 1996). Although this cannot not account for the establishment of elected local government it is consistent with its operation over the last two decades. In the large cities in particular, where competing factions possess organizational resources, local electoral politics increasingly mirrors the factional politics at the national level. The theory of electoral authoritarianism is another paradigm closer to my interpretation of the evidence, but researchers have only applied it to Iran in relation to national level elections (Brumberg and Farhi 2016, Ghobadzadeh and Rahim 2016). Thus this paper extends EA to the local level. Under local electoral authoritarianism the central state or regime effectively deploys local politics to enhance its dominance rather than permit the dispersal power centers reflecting the degree of societal pluralism. Future research might explore the nature and variation of demands across different Iranian localities in order to gauge the degree to which central state dominance is thwarting preexisting demands and preferences of the electorate.

Three other lines of literature are relevant for situating the findings of this article. Harris (2017) argues that the expansion of social welfare policy in Iran starting in the 1990s the period when the IRI was designing elected local government - reflected a shared commitment among regime elites to a developmentalist approach to state-building, its expansion was a response to bottom-up claims for social benefits; the result was a socialwelfare compact between competing elites and a range of social groups pursuing primarily their political and economic, and not ideological, interests. Was political decentralization a result of similar dynamics? While future research would profit from a closer look at the overlaps of the two cases of state expansion, the case of presented here indicates important divergences. Political decentralization was only partly an expression of developmentalism - it competed with two other visions, Islamism and democratization. And while developmentalism has become the dominant orientation of local government, nonetheless local electoral institutions possess a potential to become a space for growing factional political competition.

The literature documents another intriguing parallel in the successful campaign by residents of the city of Ardebil for the creation of province (ostan) of Ardebil in 1993 - at precisely the same time that the parliament was debating a political decentralization law. 
Chehabi (1997) argues that the incident reveals that the nature of territorial administration in Iran provides opportunities for bottom-up pressure and for lobbying of central government and that these demands reflect a desire for local autonomy from central government "tutelage." Does this contradict my claim that the political decentralization reforms were not the result of a bottom-up demands for greater local autonomy? Does the provincehood of Ardebil imply a gain in local democracy? In fact, winning provincehood is quite distinct from acquiring the right to vote for municipals officials in one crucial respect. Gaining provincehood under Iran's unitary state framework cannot enhance local democratic autonomy from central government in the way political decentralization could because the Ministry of Interior appoints the new officials in charge of the province from above. Thus managing provinces does not present the regime with the same challenging trade-off between legitimation and control as locally elected bodies do. One consequence is that the pressures on the central state to control participation, legislation, and fiscal autonomy of elected local government is not relevant for provinces.

Finally, an important line of literature argues that the failure of democratization in modern Iran can be traced to the over centralization of the state (Gheissari and Nasr 2006). One recent study traces the failure of democratization in Iran to a "centralizing power relying (...) on repression (...) excluding a vast majority of the population from the polity" (Parsa 2016, p. 296). But then, how to account for the decision to decentralize politically and to integrate thousands of Iranians as voters and candidates for local elected office into the electoral machinery of the regime? Looking at decentralization helps us see that an overly general and undifferentiated concept of centralization (or concentration of power) by itself cannot help answer this question because it obscures some of the most salient features of the way state power has evolved in Iran over the last half century; it also conceals how contention over democratization has proceeded and the means whereby challenges to the Islamic state have been contained. Interpreting centralization solely as an index of despotic power - the capacity of the state to undertake actions without routine, institutionalized negotiation with civil society groups (Mann 2012) - obscures the ways in which the Islamic Republic of Iran has consolidated its rule not only by the exclusion of interest groups from the polity, but also through integrating a large part of the population by means of (carefully calibrated) local popular participation.

\section{References}

Acemoglu, D., 2013. State Building: A Political Economy Perspective Northwestern [online]. Lecture. Available from: https://economics.mit.edu/files/8819 [Accessed 13 February 2019].

Acemoglu, D., and Robinson, J.A., 2006. Economic Origins of Dictatorship and Democracy. Cambridge/New York: Cambridge University Press.

Ang, Y.Y., 2016. How China Escaped the Poverty Trap. Ithaca: Cornell University Press.

Arjomand, S.A., 1989. The Turban for the Crown: The Islamic Revolution in Iran. New York: Oxford University Press. 
Arjomand, S.A., 2000. Civil Society and the Rule of Law in the Constitutional Politics of Iran Under Khatami. Social Research [online], 67(2), 283-301. Available from: https://www.jstor.org/stable/40971474 [Accessed 13 February 2019].

Arjomand, S.A., 2012. After Khomeini: Iran Under his Successors. New York: Oxford University Press.

Avaleen dore-ye entekhabat shorahaye eslami shahr va roosta bargozar shod

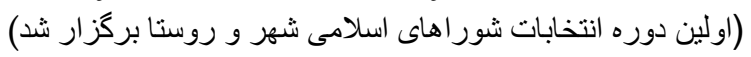

[First round of Islamic city and village councils were held], no date [online]. Available from:

http://www.tarikhirani.ir/fa/events/3/EventsDetail/90/رويدادها.و.وقايع.html [Accessed 13 February 2019].

Ayee, J.R.A., 1997. The Adjustment of Central Bodies to Decentralization: The Case of the Ghanaian Bureaucracy. African Studies Review [online], 40(2), 37-57. Available from: https://doi.org/10.2307/525156 [Accessed 13 February 2019].

Baktiari, B., 1996. Parliamentary Politics in Revolutionary Iran: The Institutionalization of Factional Politics. Gainesville: University Press of Florida.

Bardhan, P., and Mookherjee, D., 2000. Capture and Governance at Local and National Levels. The American Economic Review [online], 90(2), 135-139. Available from: https://doi.org/10.1257/aer.90.2.135 [Accessed 13 February 2019].

Bardhan, P.K., and Mookherjee, D., eds., 2006. Decentralization and Local Governance in Developing Countries: A Comparative Perspective. Cambridge, MA: MIT Press.

Bayadi, H., 2010. Tarikhcheh-ye mokhtasar entekhabat shoraha [ (تاريخجه مختصر انتخابات شور اها) [A short history of the local council elections]. Fararu [online], 29 April. Available from: https://fararu.com/fa/news/46515/تناريخجات شور اها-انتخابات-مختصر 13 February 2019].

Bird, R.M., and Vaillancourt, F., eds., 1998. Fiscal Decentralization in Developing Countries. Cambridge/New York: Cambridge University Press.

Bohlken, A.T., 2016. Democratization from Above: The Logic of Local Democracy in the Developing World. New York: Cambridge University Press.

Brownlee, J., 2007. Authoritarianism in an Age of Democratization [online]. Cambridge/New York: Cambridge University Press. Available from: http://dx.doi.org/10.1017/CBO9780511802348 [Accessed 13 February 2019].

Brumberg, D., and Farhi, F., 2016. Introduction: Politics of Contention and Conciliation in Iran's Semiautocracy. In: D. Brumberg and F. Farhi, eds., Power and Change in Iran: Politics of Contention and Conciliation. Bloomington: Indiana University Press, pp. 1-33.

Cammett, M., and Luca, D., 2018. Local winners and losers in Erdoğan's Turkey. Economic Research Forum [online], 19 June. Belfer Center of the Harvard Kennedy School of Government. Available from: https://www.belfercenter.org/publication/local-winners-and-losers-erdogansturkey [Accessed 13 February 2019]. 
Cheema, A., Khwaja, A.I., and Qadir, A., 2005. Decentralization in Pakistan: Context, Content and Causes. KSG Working Paper No. RWP05-034 [online]. Available from: http://dx.doi.org/10.2139/ssrn.739712 [Accessed 13 February 2019].

Chehabi, H.E., 1997. Ardabil Becomes a Province: Center-Periphery Relations in Iran. International Journal of Middle East Studies [online], 29(2), 235-253. Available from: https://doi.org/10.1017/S0020743800064485 [Accessed 13 February 2019].

Cleary, M.R., 2010. Sources of Democratic Responsiveness in Mexico. University of Notre Dame Press.

Cohen, J.L., 2012. Globalization and Sovereignty: Rethinking Legality, Legitimacy and Constitutionalism [online]. Cambridge University Press. Available from: https://doi.org/10.1017/CBO9780511659041 [Accessed 13 February 2019].

Court of Administrative Justice, 2016. ray-e shomare 571 hayat umumi divan edalat edari ba mozu: ebtal band 25 az mosavabe sal 1393 shuraye eslami shahr Kerman...

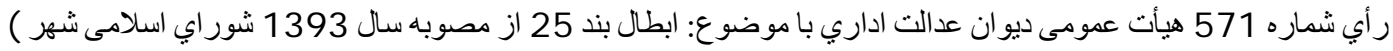

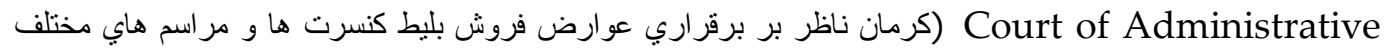
Justice, 21 November.

Court of Administrative Justice, 2017. mozu-e rayy: ebtal band avval payvast shomarey-e panj sanad asli tarhe jame-e shahr Tehran... 26 February

موضوع رأى: ابطال بند اول بيوست شماره بنج سند اصلى طرح جامع شهر تهران در سال 1386 و ماده 2 مصوبه تعبيين ضو ابط مالى

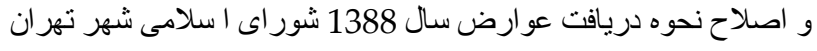

Dahl, R.A., 1998. On Democracy. New Haven: Yale University Press.

Dahl, R.A., 1998. Polyarchy: Participation and Opposition. 26. print. New Haven: Yale University Press.

Distelhorst, G., and Hou, Y., 2017. Constituency Service under Nondemocratic Rule: Evidence from China. The Journal of Politics [online], 79(3), 1024-1040. Available from: https://doi.org/10.1086/690948 [Accessed 13 February 2019].

Eaton, K., 2003. Can Politicians Control Bureaucrats? Applying Theories of Political Control to Argentina's Democracy. Latin American Politics and Society [online], 45(4), 33-62. Available from: https://doi.org/10.1111/j.1548-2456.2003.tb00257.x [Accessed 13 February 2019].

Ebel, R.D., and Yilmaz, S., 2002. On the Measurement and Impact of Fiscal Decentralization. World Bank Policy Research Working Paper №. 2809 [online]. March. Available from: https://ssrn.com/abstract=636092 [Accessed 13 February 2019].

Esmaili, G.H., 2017. Gelaye-ye rais dadgostari tehran az taeed salahiat barkhi mahkumeen amniati baraye entekhab shoraye shahr

(كلايه رئيس دادكسترى تهران از تاييد صلاحيت برخى محكومين امنيتى براى انتخابات شوراى شهر)

[Head of Tehran Judiciary complains about the approval of political dissidents to stand in local elections]. Mizan [online], 10 May. Available from:

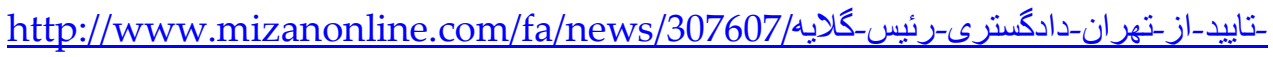

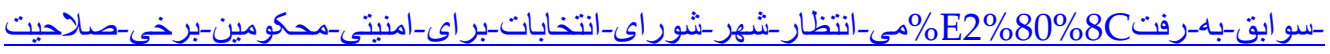

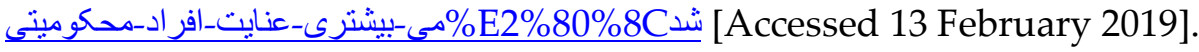


Fukuyama, F., 2012. The Origins of Political Order: From Prehuman Times to the French Revolution. $1^{\text {st }}$ paperback ed. New York: Farrar, Straus and Giroux.

Gandhi, J., and Lust-Okar, E., 2009. Elections Under Authoritarianism. Annual Review of Political Science [online], 12(1), 403-422. Available from:

https://doi.org/10.1146/annurev.polisci.11.060106.095434 [Accessed 13 February 2019].

Gandhi, J., and Przeworski, A., 2006. Cooperation, cooptation, and rebellion under dictatorships. Economics and Politics [online], 18(1), 1-26. Available from: https://doi.org/10.1111/j.1468-0343.2006.00160.x [Accessed 13 February 2019].

Gheissari, A., and Nasr, S.V.R., 2006. Democracy in Iran: History and the Quest for Liberty. Oxford/New York: Oxford University Press.

Ghobadzadeh, N., and Rahim, L.Z., 2016. Electoral theocracy and hybrid sovereignty in Iran. Contemporary Politics [online], 22(4), 450-468. Available from: https://doi.org/10.1080/13569775.2016.1175097 [Accessed 13 February 2019].

Grindle, M.S., 2009. Going Local: Decentralization, and the Promise of Good Governance. $1^{\text {st }}$ paperback print. Princeton University Press.

Harris, K., 2017. A Social Revolution: Politics and the Welfare State in Iran. Oakland: University of California Press.

Hashemi, N., 2014. Renegotiating Iran's Post-Revolutionary Social Contract. In: M. Kamrava, ed., Beyond the Arab Spring [online]. Oxford University Press, pp. 191222. Available from: https://doi.org/10.1093/acprof:oso/9780199384419.003.0008 [Accessed 13 February 2019].

Huntington, S.P., 2006. Political Order in Changing Societies. New Haven: Yale University Press.

Ivanyna, M., and Shah, A., 2012. How Close Is Your Government to Its People? Worldwide Indicators on Localization and Decentralization. Policy Research Working Paper 6138 [online]. Washington, DC: World Bank. Available from: http://documents.worldbank.org/curated/en/534401468340175192/pdf/WPS6138.p df [Accessed 13 February 2019].

Jackiewicz, A., 2012. The Principles of Unitarism, Subsidiarity and Decentralization As A Constitutional Basis Of Regional Self-Government Of The Republic Of Poland. Studies in Logic, Grammar and Rhetoric [online], 31(44), 175-189. Available from: http://logika.uwb.edu.pl/studies/download.php?volid=44\&artid=ja\&format=PDF [Accessed 13 February 2019].

Javadi-Amoli, A., 2010. Vali Faqih, Vali Feqahat va Edalat (لايت فقيه ، ولايت فقاهت و عدالت) Qom: Esra.

Kadivar, M.A., 2013. Alliances and Perception Profiles in the Iranian Reform Movement, 1997 to 2005. American Sociological Review [online], 78(6), 1063-1086. Available from: https://doi.org/10.1177/0003122413508285 [Accessed 13 February 2019]. 
Kamrava, M., 2001. The Civil Society Discourse in Iran. British Journal of Middle Eastern Studies [online], 28(2), 165-185. Available from:

https://doi.org/10.1080/13530190120083068 [Accessed 13 February 2019].

Kamrava, M., 2014. The Rise and Fall of Ruling Bargains in the Middle East. In: M. Kamrava, ed., Beyond the Arab Spring. Oxford University Press, pp. 17-46. Available from: https://doi.org/10.1093/acprof:oso/9780199384419.003.0002 [Accessed 13 February 2019].

Katznelson, I., 2003. Desolation and enlightenment: political knowledge after total war, totalitarianism, and the Holocaust [online]. New York: Columbia University Press. Available from: https://www.jstor.org/stable/10.7312/katz11194 [Accessed 13 February 2019].

Keshavarzian, A., 2005. Contestation without democracy: elite fragmentation in Iran. In: M.A. Posusney and M.P. Angrist, eds., Authoritarianism in the Middle East: Regimes and Resistance. Boulder: Lynne Rienner.

Khatam, A., 2000. Kongereye manshur shahr Tehran: avaleen tajrobeye tadvin yek misaq shahri (كنكره منشور تهران: اولين تجربه تدوين يك ميثاق شهرى) [Tehran Charter Congress: The first ever experience of a city charter]. Gofte-Gu, 30(30), 184-87.

Khemani, S., 2015. Political Capture of Decentralization [online]. In: J.P. Faguet and C. Pöschl, eds., Is Decentralization Good for Development? Oxford University Press, pp. 196-223. Available from:

https://doi.org/10.1093/acprof:oso/9780198737506.003.0009 [Accessed 13 February 2019].

Landry, P.F., 2008. Decentralized Authoritarianism in China: The Communist Party's Control of Local Elites in the Post-Mao Era. Cambridge/New York: Cambridge University Press.

Lewis, J.I., 2014. When Decentralization Leads to Recentralization: Subnational State Transformation in Uganda. Regional \& Federal Studies [online], 24(5), 571-588. Available from: https://doi.org/10.1080/13597566.2014.971771 [Accessed 13 February 2019].

Linz, J.J., 1975. Totalitarian and Authoritarian Regimes. In: F.I. Greenstein and N.W. Polsby, eds., Handbook of Political Science (vol. 3). Reading: Addison-Wesley, 18283.

Linz, J.J., and Stepan, A.C., 1996. Problems of Democratic Transition and Consolidation: Southern Europe, South America, and Post-Communist Europe. Baltimore: Johns Hopkins University Press.

Majlis Proceedings. Local Council Bill. May 24, 1994. Session \#228, 3/3/1373.

Majlis Proceedings. Conformance Committee bill. May 9, 2016.

Manion, M., 1996. The Electoral Connection in the Chinese Countryside. American Political Science Review [online], 90(04), 736-748. Available from: https://doi.org/10.2307/2945839 [Accessed 13 February 2019]. 
Mann, M., 2012. The Sources of Social Power (vol. 2) $2^{\text {nd }}$ ed. New York: Cambridge University Press.

Mansuri, G., and Rao, V., 2012. Localizing Development: Does Participation Work? Washington, DC: World Bank.

Misbah Yazdi, M.T. (with Subhani, K., ed.), 2001. Nazariyyeh-ye Siyasi-ye Islam Qanunguzari [Political Theory in Islam] (vol. 2). Qom: Imam Khomeini Educational and Research Institute.

Mookherjee, D., 2015. Political Decentralization. Annual Review of Economics [online], 7(1), 231-249. Available from: https://doi.org/10.1146/annurev-economics-080614115527 [Accessed 13 February 2019].

Mousazadeh, I., and Sohrablu, A., 1394. Salahiat vaze avarez va usul hakem bar an dar parto araye divan edalat edari

صلاحيت وضع عو ارض و اصول حاكم بر آن در برتو آراى ديوان عدالت ادارى

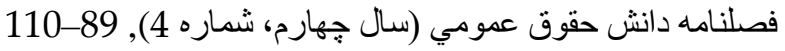

[Taxing Authority in Iran in light of the rulings of the Court of Administration Justice]. Faslnameh Danesh hughugh umumi (Year 4, No. 4), 110-89

Nisbet, R.A., 1976. Emile Durkheim. Westport: Greenwood Press.

Nisbet, R.A., 2010. The quest for community: a study in the ethics of order and freedom. New critical ed. Wilmington: ISI Books.

OECD/UCLG, 2016. Subnational Governments around the World: Structure and Finance [online]. Available from: https://www.oecd.org/regional/regionalpolicy/Subnational-Governments-Around-the-World-\%20Part-I.pdf, p. 20 [Accessed 12 February 2019].

Offe, C., 1998. "Homogeneity" and Constitutional Democracy: Coping with Identity Conflicts through Group Rights. Journal of Political Philosophy [online], 6(2), 113-

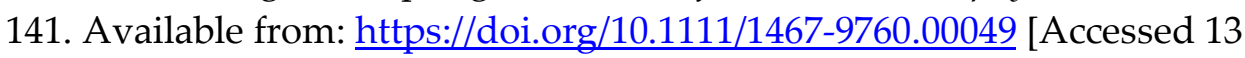
February 2019].

Offe, C., 2006. Political Disaffection as an Outcome of Institutional Practices? Some Post-Tocquevillean Speculations. In: M. Torcal and J.R. Montero, eds., Political Disaffection in Contemporary Democracies: Social Capital, Institutions and Politics. London/New York: Routledge.

Parsa, M., 2016. Democracy in Iran: Why it Failed and How it Might Succeed. Cambridge, MA/London: Harvard University Press.

Putnam, R.D. (with R. Leonardi and R. Nanetti), 1994. Making Democracy Work: Civic Traditions in Modern Italy. 5. print., 1. Princeton paperback print. Princeton University Press.

Reuter, O.J., et al., 2016. Local Elections in Authoritarian Regimes: An Elite-Based Theory with Evidence From Russian Mayoral Elections. Comparative Political Studies [online], 49(5), 662-697. Available from: https://doi.org/10.1177/0010414015626439 [Accessed 13 February 2019]. 
Sarabi, F., 1994. The Post-Khomeini Era in Iran: The Elections of the Fourth Islamic Majlis. Middle East Journal [online], 48(1), 89-107. Available from: https://www.jstor.org/stable/4328663 [Accessed 13 February 2019].

Schedler, A., ed., 2006. Electoral Authoritarianism: The Dynamics of Unfree Competition. Boulder: Lynne Rienner.

Schirazi, A., 1998. The Constitution of Iran: Politics and the State in the Islamic Republic. Trans.: J. O'Kane. Paperback ed. London: I.B. Tauris.

Stack, K.M., 2015. An Administrative Jurisprudence: The Rule of Law in the Administrative State. Columbia Law Review [online], 115(7), 1985-2018. Available from: https://columbialawreview.org/content/an-administrative-jurisprudencethe-rule-of-law-in-the-administrative-state-2/ [Accessed 13 February 2019].

Tajbakhsh, K., 2006. Decentralization, Municipal Management and Local Economic Development in Iran. Draft, unpublished. Washington, DC: World Bank, Finance, Private Sector Development and Infrastructure Group Middle East and North Africa Region, May.

Tajbakhsh, K., 2019. What are Iranians Dreaming about Today? Three Narratives of Transition and Utopia. Social Research: An International Quarterly [online], 86(1). Available from: https://muse.jhu.edu/article/725998 [Accessed 20 May 2020].

Tajzadeh, M., 2017. Gofte-gu Hossein Dehbashi ba Mostafa Tajzadeh. (خشت خام /نوبت جهاردهم/ كفتخوى حسين دهبانشى با مصطفى ناج زاده). [A conversation with Mostafa Tajzadeh by Hossein Dehbashi] (Video clip). Tarikh Online [online], 20 January. Available from:

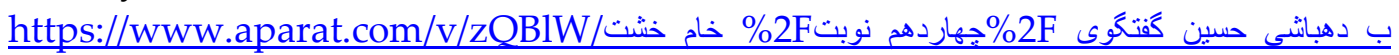
[Accessed 13 February 2019].

Teets, J.C., 2014. Civil Society under Authoritarianism: The China Model [online]. New York: Cambridge University Press. Available from: https://doi.org/10.1017/CBO9781139839396 [Accessed 13 February 2019].

Tezcür, G.M., 2012. Democracy promotion, authoritarian resiliency, and political unrest in Iran. Democratization [online], 19(1), 120-140. Available from: https://doi.org/10.1080/13510347.2012.641296 [Accessed 13 February 2019].

The Iran Social Science Data Portal, no date. Political Parties. The Iran Social Science Data Portal [online]. Available from: http://irandataportal.syr.edu/political-parties [Accessed 13 February 2019].

Tilly, C., 1975. Reflections on the History of European State-Making. In: C. Tilly, ed., The Formation of National States in Western Europe. Princeton University Press.

Truex, R., 2016. Making Autocracy Work: Representation and Responsiveness in Modern China. New York: Cambridge University Press.

Weber, M. (with G. Roth and C. Wittich, eds.), 2013. Economy and Society: An Outline of Interpretive Sociology (vols. 1-2). Berkeley: University of California Press.

Wimmer, A., 2018. Nation Building: Why Some Countries Come Together While Others Fall Apart. Princeton University Press. 
Woloch, I., 1994. The New Regime: Transformations of the French Civic Order, 1789-1820s. $1^{\text {st }}$ ed. New York: W.W. Norton.

Wu, F., Xu, J., and Yeh, A.G.O., 2007. Urban Development in Post-Reform China: State, Market, and Space. Abingdon/New York: Routledge. 